\title{
UNIVERSITY OF PENNSYLVANIA RADIOCARBON DATES XX
}

\section{BERNARD FISHMAN and BARBARA LAWN}

Department of Physics and University Museum

University of Pennsylvania, Philadelphia, Pennsylvania 19104

\section{INTRODUCTION}

In this date list we have included most of the archaeologic samples dated in this laboratory since publication of our last date list $(\mathrm{R}, 1977$, v 19, p 188-228).

The BP ages are based on AD 1950, and have been calculated with the half-life value of $5568 \mathrm{yr}$. An asterisk (*) before an AD/BC date indicates a date that has been calculated with the half-life value of $5730 \mathrm{yr}$ and then corrected by means of MASCA correction factors. For further explanation see Univ of Pennsylvania Dates XVI (R, 1974, v 16, p 198-218) and Ralph et al, 1973, p 1-20.

All samples were counted at least twice for periods of not less than $1000 \mathrm{~min}$ each. Errors quoted for each sample include the statistical counting uncertainties in the measurement of the sample, the background, and the running mean of several counts of our mid-19th century oak sample, but do not include any additional errors associated with the correction factors.

In addition to our $28 \mathrm{~L}$ counters, a small $1 \mathrm{~L}$ counter is employed for counting undersized samples. Larger errors associated with these dates are a direct result of small sample size and the consequently reduced number of counts. Samples counted in the small counter have been so noted. We continue to use pure $\mathrm{CO}_{2}$ in the proportional counters.

All samples were pretreated with $3 \mathrm{~N}$ HCL, and some, where noted, were given additional pretreatment with $2 \% \mathrm{NaOH}$ for the removal of possible humic acid contaminants.

Our mid-19th century calibration samples have an average age of 141 years. When corrected for this age, they have ${ }^{14} \mathrm{C}$ contents equal to $95 \%$ of the NBS oxalic standard.

For the design and construction of various new components, we wish to thank Jeffrey Klein. The samples described in this list have been processed by Anne Meulengracht and the authors. The date list itself was compiled and composed by Bernard Fishman, while Barbara Lawn was responsible for its editing, and for the guidance under which it was written.

\section{ACKNOWLEDGMENTS}

We acknowledge with gratitude the financial assistance of the $\mathrm{Na}$ tional Science Foundation, through continuing grant EAR-74-22233, Earth Sciences Division, for the known-age dating program at the Univ of Pennsylvania which has resulted in the MASCA correction factors used in this list. We are also grateful to the William Penn Foundation and 
the Jewish Communal Fund of New York, for each supporting one graduate student. To the Univ of Pennsylvania itself we wish to extend our profound thanks for its continuing support of our endeavors.

\section{SAMPLE DESCRIPTIONS}

\section{ARCHAEOLOGIC SAMPLES}

\section{A. Mediterranean}

\section{Aegean Bronze Age}

Most of the following samples have chronologic significance for dating Bronze age remains in various parts of the Aegean. Betancourt and Weinstein ( $\mathrm{ms}$ in preparation; 1976; hereafter PB-GW) analyzed these and other radiocarbon dates to study patterns of Aegean chronology. They have noted that major discrepancies between ${ }^{14} \mathrm{C}$ dates (using MASCA correction factors) and dates based on traditional systems are particularly pronounced for the Late Helladic I/Late Minoan IA and the Late Minoan II periods, while ${ }^{14} \mathrm{C}$ dates from later stages of the Aegean Bronze age show more exact correlations. Reasons for these inconsistencies have not yet been satisfactorily resolved, and some revision of heretofore accepted traditional chronology may possibly be in order.

\section{Crete}

\section{Knossos, Unexplored Mansion series}

Samples are from Late Minoan II destruction level of "Unexplored Mansion" at Knossos, Crete ( $35^{\circ} 20^{\prime} \mathrm{N}, 25^{\circ} 09^{\prime} \mathrm{E}$ ). Samples lay some $2 \mathrm{~m}$ below top of surviving walls in debris, including charcoal and sherds, all overlain by $3 \mathrm{~m}$ of later occupational deposition ending in 3rd century BC. Initial and perhaps incomplete construction of bldg dates to Late Minoan IA period (conventionally ca 1550 to $1500 \mathrm{BC}$ ), then followed by levelling of interior and eventual completion of structure in Late Minoan II period (conventionally ca 1450 to $1425 \mathrm{BC}$ ). Minor fire damage and subsequent repairs preceded final LM II destruction. For other Knossos dates, see R, 1963, v 5, p 104-105; R, 1969, v 11, p 157-159, 279-280; R, 1977, v 19, p 145, and Palace series below. Coll 1972, subm 1973 by M R Popham, Linacre Coll, Oxford Univ, Oxford.

General Comments: wood id by R C Koeppen, Forest Prods Lab, US Dept Agric, Madison, Wisconsin. (MRP, PB-GW): re-use of timber beams may explain unusually early dates displayed by all samples in series.

\section{P-2045. Sample 1}

$3320 \pm 50$

Charred softwood (probably Cupressus sempervirens) from basement $\mathrm{Rm} 21$, portion of either beam or wall cupboard. Comment: $\mathrm{NaOH}$ pretreatment. 
P-2048. Sample 4

Charred softwood (probably Cupressus sempervirens) from basement $\mathrm{Rm} 21$; portion of either roof beam or wall cupboard. Comment: $\mathrm{NaOH}$ pretreatment.

\section{P-2048-A. Sample 4}

$3460 \pm 50$

Portion of P-2048, above. Comment: NaOH pretreatment. Date unexpectedly inconsistent with P-2048.

\section{P-2046. Sample 2}

$3820 \pm 50$

Charred resin, id by R C Koeppen, although subm as burnt wood. Found in doorway between basement $\mathrm{Rms} 33$ and 21, from part of either roof beam or wall cupboard. Comment: $\mathrm{NaOH}$ pretreatment.

\section{P-2047. Sample 3}

$3930 \pm 70$

Charred wood from basement Rm 31, probably portion of roof beam.

\section{Knossos, Palace series}

Samples from trial soundings in palace of Knossos, Crete $\left(35^{\circ} 20^{\prime} \mathrm{N}\right.$, $25^{\circ} 09^{\prime} \mathrm{E}$ ). Unless otherwise stated, coll 1973, subm 1974 by W M S Hood, Oxford Univ, Oxford.

\section{P-2512. Sample 15}

$2310 \pm 70$

Charcoal, Knossos Survey Provisional No. 326, from base of kiln used for burning gypsum. Coll 1976 and subm by W M S Hood. Comments: $\mathrm{NaOH}$ pretreatment. Sample counted in small counter. (WMSH): although no archaeol evidence relevant to date of this kiln exists, it may be of Roman period.

\section{P-2444. Sample 9, 10, 11, and 14}

$3440 \pm 90$ Comment (WMSH): expected date ca 1550 BC.

\section{P.2441. Sample 1}

$3060 \pm 60$

Wood charcoal, Provenience $\mathrm{C} V$ 3, from remaining sec of floor $S$ Terrace basements originally excavated by Sir Arthur Evans in 19001901. Comment (WMSH): sample recovered ca $5 \mathrm{~cm}$ below old excavation surface. Presumably dates final destruction of palace early in Late Minoan IIIA or within lst half of Late Minoan IIIB, ca 1400 to $1250 \mathrm{BC}$. 
$3720 \pm 220$

P-2442. Sample 4

$* 2180 \pm 230 \mathrm{BC}$

Wood charcoal, Provenience D.VII.14, Level 10, from Middle Minoan IB destruction level. Comment: sample counted in small counter. Large uncertainty allows agreement with expected date, ca 1900 BC.

\section{P.2443. Sample 5}

$3890 \pm 70$

$* 2480-2440 \pm 70$ BC

Wood charcoal, Provenience D.VII.14, Level II, from Middle Minoan IB destruction level.

\section{Pyrgos series}

Pyrgos, near village of Myrtos, Crete $\left(35^{\circ} 00^{\prime} \mathrm{N}, 25^{\circ} 36^{\prime} \mathrm{E}\right)$, is multiphase Minoan habitation site, which yielded remains from Early Minoan II to Late Minoan IB periods (Catling, 1974). Relation between LM IB destruction of Pyrgos and any volcanic activity uncertain, although trace levels of pyroclastic materials were recovered from site (Cadogan et al, 1972). Unless otherwise stated, Samples P-2113, -2116 coll 1970 by Mrs. Henry Hankey, subm 1972 by Gerald Cadogan, Univ Cincinnati, Cincinnati, Ohio; Samples P-2339, -2353 coll 1973 by Jill CaringtonSmith, subm 1975 by Gerald Cadogan.

\section{P-2113. Sample 3, MP/70}

$3320 \pm 60$ $* 1680 \pm 60$ вС

Bitter vetch, id as Vicia ervilia by Jane Renfrew, from E Storeroom 9 of "country house" destroyed by fire in LM IB period. Sample represents contents of broken pithos found 0.5 to $0.7 \mathrm{~m}$ below modern surface. Comments: $\mathrm{NaOH}$ pretreatment. (PB-GW): date is not only early, but archaeologically predates earlier LM IA dates from Thera.

\section{P-2114. Sample 4, MP/70}

$3320 \pm 60$

Hulled 6-row barley, id by Jane Renfrew, from E Storeroom 9 of "country house" destroyed by fire in LM IB period. Comments: $\mathrm{NaOH}$ pretreatment. (PG-GW): this date, like P-2113 above, is unexpectedly early.

\section{P-2115. Sample 2, MP/70}

$3350 \pm 60$

$* 1710-1690 \pm 60 \mathrm{BC}$

Portion of carbonized beam, perhaps cypress, from paved Corridor 7 leading to Storerooms 8 and 9, Balk J5-J6, Level 2, in LM IB destruction deposit. Coll 1971. Comments: $\mathrm{NaOH}$ pretreatment. (PB-GW): re-use of older wood perhaps explains anomalously early date, which agrees with 2 Pyrgos dates from short-lived samples (see P-2113 and -2114, above).

\section{P-2116. Sample 1, MP/70}

$3440 \pm 60$

Portion of carbonized beam, perhaps cypress, 0.10 to $0.20 \mathrm{~m}$ diam. From house courtyard, Level 6 (W), in LM IB destruction deposit. Com- 
ments: $\mathrm{NaOH}$ pretreatment. (PB-GW): re-use of older wood perhaps explains anomalously early date. $(\mathrm{GC})$ : date is, however, properly older than short-loved samples P-2113 and -2114 above.

P-2343. Sample 5, MP/73

$3560 \pm 60$

(1) From "country house" of LM IB destruction which produced P-2113 and -2116, above. Comment (GC): sample should provide a check for P-2113 and -2116, and seems to confirm 1st group of dates for LM IB destruction.

\section{P-2344-A. Sample 6, MP/73}

$\mathbf{3 4 1 0} \pm \mathbf{7 0}$

Charcoal from Trench H7/J7, Level 3, IM IB destucion "coun try house". Comments: NaOH pretreatment (GC): vide a check for P-2113 and -2116. (PB-GW): early date agrees with P-2113 and -2114, above.

\section{P-2341. Sample 3, MP/73}

$$
\begin{array}{r}
3670 \pm 230 \\
* 2150 \pm 240 \text { BC }
\end{array}
$$

Charcoal from Trench EO 1, Level 6, Basket 3334, Pyrgos Period III. Comments: sample counted in small counter. (GC): should date construction of large Middle Minoan cistern on N slope of hill.

\section{P-2347. Sample 9, MP/73}

$3430 \pm 70$

$* 1900-1780 \pm 70 \mathrm{BC}$

Charcoal from S and E of Trench Z3, Level 2, Basket 3633, Pyrgos Periods ? IId/III. Comments (GC): presumably dates to some point in Middle Minoan sequence.

\section{P.2350. Sample 12, MP/73}

$3770 \pm 370$

Charcoal from Trench Com Charcos Period II. Comments: sample counted in small counter. (GC): sample seems to belong to destruction level of mostly MM date.

\section{P-2351. Sample 13, MP/73}

$3790 \pm 300$

Charcoal from Trench Z4, Level 14, Basket 3235, late Pyrgos Period II. Comments: sample counted in small counter. (GC): sample perhaps from posthole, and seems to belong to destruction level of mostly MM date.

\section{P-2339. Sample 1, MP/73}

$5590 \pm 350$

Charcoal from NE corner of Trench A3, Level 10 (14), Basket 3785, Pyrgos Period IIC. Assoc with Floor W of "funeral drive", roadway constituting part of Early Minoan III/Middle Minoan IB funerary complex. Comment: sample counted in small counter. 
P-2340. Sample 2, MP/73

$3560 \pm 200$

$* 2070 \pm 210 \mathrm{BC}$

Charcoal from S and E part of Trench B2, Level 3, Basket 3379, Pyrgos Period ? III. Comments: sample counted in small counter. (GG): period uncertain, but either EM II/MM IA or elsewhere in MM sequence.

P-2348. Sample 10, MP/73

$3700 \pm 230$

$* 2160 \pm 240 \mathrm{BC}$

Charcoal from Trench Z3, Level 11, Basket 3644, Pyrgos Period I/IIa. Comments: sample counted in small counter. (GG): presumably dates to EM II to EM III/MM IA period, earliest date for traces at Pyrgos.

P-2349. Sample 11, MP/73

$3990 \pm 70$

Charcoal from Trench 73, Level 11, Basket 3644, Pyroos Period I/IIa. Comment (GC): possibly from EM II destruction debris overlain by rd and courtyard belonging to EM III/MM IA funerary complex.

\section{P-2353. Sample 15, MP/73}

$4390 \pm 280$

Charcoal from Trench Z4, Level 23, Basket 3261, Pyrgos Period ? IIb. Sample found below Floor VIII, earliest excavated floor, and below funerary complex rd. Comments: sample counted in small counter. (GC): probably belongs to EM II destruction level.

\section{Akrotiri Series II}

Cyclades

Akrotiri, on I. of Thera (Santorini), Cyclades, Greece $\left(36^{\circ} 16^{\prime} \mathrm{N}\right.$, $\left.25^{\circ} 27^{\prime} \mathrm{E}\right)$, is multiphase settlement overwhelmed by volcanic eruption in Late Cycladic I (Late Minoan IA) period. Earliest remains at site are of Middle Cycladic date. For discussion of problems assoc with this and an earlier series (I) of Akrotiri dates (R, 1977, v 19, p 191-193), see Betancourt and Weinstein ( $\mathrm{ms}$ in preparation; 1976), Michael (1976), and Pichler and Friedrich (1976). All samples from pithoi in Rm 5, Ground Floor of W House. Coll and subm 1976 by Christos Doumas, Rhodes Mus, Rhodes.

General Comment (CD): samples should date final destruction of site, conventionally placed at ca 1500 BC. (PB-GW): this 2nd series of dates is inconsistent both internally and with 1st series of Akrotiri dates. But it does suggest an early trend despite its wide range.

P.2559. Sample 1976.7

Grain from pithos pi 1, delta 2 .

P.2560. Sample 1976.1

Grain from pithos pi 2, delta 1 .
$3370 \pm 70$

$* 1750-1710 \pm 70$ вС

$3980 \pm 70$

$* 2590 \pm 70$ BC 
P-2561. Sample 1976.2

Grain from pithos pi 3, delta 1 .

P-2562. Sample 1976.3

Organic matter in small counter.

P-2563. Sample 1976.4

Organic matter from pithos pi 16, delta 3. Comment: sample counted in small counter.

\section{P-2564. Sample 1976.5}

Organic matter from pithos pi 9, delta 3. Comment: sample counted in small counter.

\section{P-2565. Sample 1976.6}

Grain from pithos pi 5, delta 2.

\section{P-2566. Sample 1976.8} in small counter.

\section{Ayia Irini series}

Ayia Irini, in bay of Ayios Nikolaos, Kea, Cyclades, Greece (37० 42' $\mathrm{N}, 24^{\circ} 18^{\prime} \mathrm{E}$ ), is stratified site which, so far, yielded remains dating from Neolithic into Late Helladic IIIC periods (Caskey, 1971; 1972). Previous dates for samples from Ayia Irini are reported in R, 1969, v 11, p 156-157. Samples coll 1963 to 1967, subm 1977 by John Caskey, Univ Cincinnati, Ohio.

\section{P-2576. Sample 3, Field No. G-7.32} IB), conventionally ca 1500 to 1450 BC. Comments: $\mathrm{NaOH}$ pretreatment. (PB-GW): date barely falls within extreme upper limit of traditional chronology.

\section{P-2579. Sample 6, Field No. A-3.642}

$$
\begin{array}{r}
3320 \pm 60 \\
* 1690 \pm 70 \text { BC }
\end{array}
$$

Charcoal from Rm I in Area A, Cuts 24 to 29, Ayia Irini Period H (LM IB). Comments (JC): sample may in fact be earlier, as some LM IA sherds in possible assoc. (PB-GW): although anomalously early, date agrees with short-lived samples P-2113 and -2114 from Pyrgos (above). 
P-2574. Sample 1, Field No. B-6.97

$3820 \pm 70$

Charcoal from Rm XV in Area B, Cuts 15, 16, \& 17, Ayia Irini Period G (LM IA, conventionally ca 1550-1500 BC). Comments: NaOH pretreatment. (PB-GW): date is too early, but may be partly explained by possible re-use of wood.

P-2578. Sample 5, Field No. M-76.7

$2920 \pm 230$ necessitating a pump for excavation), Ayia Irini Period G (LM IA, conventionally ca $1550-1500 \mathrm{BC})$. Comments: sample counted in small counter. (JLC): possible contamination from percolating ground water caused by being below sea level.

P-2575. Sample 2, Field No. G-6.20

$3350 \pm 60$

Charcoal from Rm VII in Area G, Cuts 8 \& 9 , Ayia Irini Period F (MM IIB/MM III). Comments: $\mathrm{NaOH}$ pretreatment. (PB-GW): date falls well within traditionally acceptable range.

P-2581. Sample 8, Field No. J-1.178

$3420 \pm 60$
$* 1850-1770 \pm 70$

Charcoal from Area J, Trench 4, Cuts 7, 8 \& 9, Ayia Irini Period F (MM IIB/MM III). Comment: (PB-GW) date fits upper limit of traditional chronology.

P-2577. Sample 4, Field No. E-8.26

$3500 \pm 60$ phases of Middle Bronze age).

\section{P-2580. Sample 7, Field No. C-3.498}

$* 2040-2020 \pm 70$ BC (early phases of Middle Bronze age).

Greece

\section{P-2474. Lake Vouliagmeni}

$4060 \pm 60$

* 2800-2690 \pm 60 вс

Sample 2B, charcoal from Trench AI, Level 5E, Lake Vouliagmeni, Perakhora, Greece $\left(38^{\circ} 02^{\prime} \mathrm{N}, 2^{\circ} 53^{\prime} \mathrm{E}\right)$. Sample from thick destruction level of final phase of Early Bronze II period bldg. Coll 1972, subm 1975 by John Fossey, McGill Univ, Montreal. Unpub dates for portions of same sample: DIC-448, $3900 \pm 65$; LJ-3604, $3740 \pm 40$. Other unpub dates from same destruction level elsewhere on site: DIC-452, $3880 \pm 185$ : DIC- $453,4330 \pm 210$. Other unpub dates from deposits immediately overlying this destruction: DIC-449, $4270 \pm 200$; DIC-451, $4010 \pm 105$ (personal commun). 
2. Cyprus

\section{Kalavasos-Tenta series}

Tenta, $2.25 \mathrm{~km}$ SSE of Kalavasos village, Laconia prov, Cyprus $\left(34^{\circ}\right.$ $45^{\prime} \mathrm{N}, 33^{\circ} 18^{\prime} \mathrm{E}$ ), is stratified habitation site yielding evidence of Neolithic IA (aceramic) and Neolithic II period settlements (ca 6000-4000 BC) (Dikaios, 1953; 1960; 1962). Ceramic material may also indicate Neolithic IB occupation at Tenta, which would constitute most detailed Neolithic sequence from Cyprus. Earlier phase at site is represented by Sqs G 12A and F 11D, while later phase perhaps is represented by Sq F 10B. Samples coll 1976 and subm by Ian Todd, Brandeis Univ, Waltham, Massachusetts.

\section{P-2549. Sample 1}

$5630 \pm 260$

Charcoal from Sq G 18 sumably soft "havara" form of bedrock. Comments: small counter. (IT): expected date earliest in series. Unexpectedly late date may be due to sample contamination from humic acids.

P.2548. Sample 3

$8350 \pm 200$

Charcoal from Sq G 12A, Deposit 6.3, small hearth containing burnt flints, in open area, from early phase of occupation at site. Comments: $\mathrm{NaOH}$ pretreatment. Uncorrected date calculated with 5730 half-life $=$ $6650 \pm 200$ вс. (IT): expected date, later than P-2549, above, and earlier than P-2550, below.

\section{P-2550. Sample 2}

$7180 \pm 90$

Charcoal from Sq G 12A, Deposit 5.5, small hearth containing burnt flints, in open area. Comments: uncorrected date calculated with 5730 half-life is $5450 \pm 100$ вс. (IT): expected date later than P-2549, above.

\section{P-2551. Sample 4}

$7140 \pm 90$

Charcoal from Sq G 12A, Deposit 6.3, a different part of source deposit for P-2548, above. Comments: uncorrected date calculated with 5730 half-life is $5400 \pm 100$ BC. Difference between P-2548 and -2551 could be explained by absence of $\mathrm{NaOH}$ pretreatment for P-2551. (IT): sample should be contemporary with P-2548, above.

\section{P-2552. Sample 5}

$7250 \pm 100$

Charcoal from Sq F 11D, Deposit 3.5, ashy deposit in open area near 2 circular stone structures. Comments: $\mathrm{NaOH}$ pretreatment. Uncorrected date calculated with 5730 half-life $=5520 \pm 100$ BC. (IT): sample postdates main occupation of stone structures, and should be later than P-2548-2551, above, while earlier than P-2555, below.

\section{P-2553. Sample 6}

$7110 \pm 90$

Charcoal from Sq F 11D, Deposit 3.5, ashy deposit in open area near 2 circular stone structures. Comments: $\mathrm{NaOH}$ pretreatment. Uncorrected date calculated with 5730 half-life $=5730 \pm 100$ вс. 
P-2555. Sample 7

$\mathbf{7 4 3 0} \pm 90$

Charcoal from Sq F 11D, Deposit 3.7, W of circular structure in NE corner of sq in open area. Comments: uncorrected date calculated with 5730 half-life is $5700 \pm 90$ BC. (IT): should date occupation of structure.

\section{P-2554. Sample 8}

$8480 \pm 110$

Charcoal from Sq F 10B, from hearth between 2 ring walls of structure, in open work area surrounding inner circular stone structure. Comments: $\mathrm{NaOH}$ pretreatment. Uncorrected date calculated with 5730 half-life $=6780 \pm 110$ BC. (IT): dates occupation of structure and assoc outer ring wall. Sample possibly later than other samples in series, but its stratigraphic position relative to remains in Sqs F $11 D$ and G $12 \mathrm{~A}$ is not yet clear.

\section{Iran}

\section{B. Near East}

\section{Hasanlu Tepe Series IV}

Settlement mound of Hasanlu (37 $\left.02^{\prime} \mathrm{N}, 45^{\circ} 28^{\prime} \mathrm{E}\right) \mathrm{S}$ of Lake Urmia and NW of town of Nagadeh in Solduz Valley, W Azerbaijan, Iran (Dyson, 1972; 1974; ms in preparation). Samples coll 1966 to 1974 and subm 1966 to 1975 by Robert H Dyson, Jr, Univ Mus, Univ Pennsylvania. For 3 previous series of ${ }^{14} \mathrm{C}$ dates from Hasanlu, see R, 1959, v 1, p 49-50; R, 1963, v 5, p 85-89; and R, 1966, v 8, p 349-350.

General Comment (RHD): working chronology for Hasanlu periods relevant to most of samples submitted is as follows: Hasanlu IIIA: ca 600 to 300 BC; Hasanlu IIIB: ca 780 to 600 BC; Hasanlu IVA: ca 800 BC; Hasanlu IVB: ca 1100 to $800 \mathrm{BC}$; Hasanlu IVC: ca 1250 to $1100 \mathrm{BC}$; Hasanlu V: ca 1450 to 1250 BC.

\section{P-2153. HAS-72-CI4-SI : Period IIIA}

$$
\begin{array}{r}
2350 \pm 260 \\
* 460-440 \pm 270 \mathrm{BC}
\end{array}
$$

Charcoal, Provenience BB-CC-32. From Balk E of Burned Bldg II, in large pit with layered refill cut down from Period IIIB/IVA. Comments: $\mathrm{NaOH}$ pretreatment. Sample counted in small counter. (RHD): dates to Period IIIA.

\section{P-2377. HAS-72-Ca4-S18: Period IIIA}

$$
\begin{array}{r}
2360 \pm 60 \\
* 470-440 \pm 60 \mathrm{BC}
\end{array}
$$

Charcoal and ash, Provenience Z21 (2) /1/ C14 S1. From kiln built over thin burned stratum resting on pavement assoc with curved Wall $\mathrm{A}$ in Z21. For date for pavement, see P-399, $2521 \pm 54$ ( R, 1963, v 5, p 88). Comments: $\mathrm{NaOH}$ pretreatment. (RHD): dates, as expected, to Period IIIA.

P-1881. HAS-70-C14-S32: Period IIIB/IVA $* 780 \pm 50$ BC

Wood charcoal, Provenience CC-32. From Pit 5, Balk E of Burned Bldg II. This pit was cut down from IIIB/IVA surface. Comment (RHD): dates to Period IIIB/IVA. 
P-2157. HAS-72-C14-S6: Period IIIB/IVA $* 720-660 \pm 50 \mathrm{BC}$

Charcoal, from W Gate Sec A-B, 5-2A, on W slope of Citadel Mound. Sample provenience was pit dug into stratum slightly above stratum of P-2159 (below), and was assoc with curved Wall $\mathrm{A}$ and pavement of Z21 and wall of Y20. Samples P-2382 (below) and P-399 (R, 1963, v 5, p 88) are from same complex. Comment (RHD): it is still undecided whether apparently late 8th century date should be considered Period IVA or Period IIIB.

P-2382. HAS-74-C14-S92: Period IIIB/IVA

$2440 \pm 60$

$* 710-530 \pm 60 \mathrm{BC}$

Charcoal, from Provenience Y20 (4) with Wall A, W slope of Citadel Mound. Wall A directly underlies Fortification Wall I (Period IIIA or later), and relates stratigraphically to Wall $A$ and pavement of $Z 21$ (see P-2377, above). Comment (RHD): expected date same as P-2157, above, and P-399 (R, 1963, v 5, p 88). Period either IVA or IIIB.

\section{P-2159. HAS-72-C14-S7 : Period IVA}

Charcoal, S-3A, from W Gate, Sec A-B, W slope of Citadel Mound. Sample provenience was pit dug into redeposited Period IV debris which also underlay curved Wall A and pavement (see P-2382 and -2377, above). Comment (RHD): dates of P-399, -2157, and -2382 suggest curved wall complex dates to late 8 th century BC. Thin stratum separates P-2159 from this group, which is later. Date suggests Period IVA, at end of 9 th or beginning of 8 th century BC.

\section{P-2380. HAS-74-C14-S91 : Period IVA}

$2540 \pm 50$ CiV-V (lebris $\mathrm{IV}-\mathrm{V}$ debris cut into by stratified refuse pit. Sample from Lenses 7 through 10 at base of pit. Comment (RHD): pit was cut from surface dating to Period IIIB/IV. Date appears to favor Period IVA.

\section{P-2381. HAS-74-C14-Period IVA}

$2480 \pm 70$

Charred reeds (?) Provenience W92 Po6 C14 S22a, from upper Lenses 1 through 6 in same pit as P-2380, above. Comments: sample undersized $(90.94 \%)$ in $8 \mathrm{~L}$ counter, resulting in slightly larger uncertainty than most samples in series. (RHD): date appears to favor Period IVA.

\section{P-2383. HAS-74-C14-S95: Period IVA}

$2600 \pm 50$

Charcoal, Provenience V22 (4) $/ 1 /$, stone paving on NW Citadel Mound. From paved structure overlying $\mathrm{N}$ wall of Burned Bldg VI (Periods IVG and B), and underlying walls of IIIB date attached to Fortification Wall II (Urartian). Comment: NaOH pretreatment. (RHD): date expected to be Period IVA. 
P-1230. HAS-66-C14-S1: Period IVB

$2830 \pm 60$

Charcoal, Provenience AA 30, Wall H. From N wall of anteroom of Burned Bldg II. Sample was sealed in layer between 1st and 2nd brick course during reconstruction of bldg. Comment (RHD): date should relate to rebuilding activity at beginning of Period IVB.

\section{P-2160. HAS-72-C14-S8: Period IVB}

$$
\begin{array}{r}
2750 \pm 50 \\
* 990-940 \pm 50 \mathrm{BC}
\end{array}
$$

Charcoal, Provenience S22 (10) /13/ S5, NW Citadel Mound. Sample from posthole penetrating floor of Bldg II in Period V. Comment (RHD): apparently intrusive from overlying Period IVB level.

\section{P-2374. HAS-72-C14-S15: Period IVB $*$ 1100-1030 \pm 50 BC$$
2830 \pm 50
$$

Charcoal, Provenience V31 W(2) /4/ C14 S2. From upper collapse of Burned Bldg IVE, columned hall. Bldg was reconstructed at start of Period IVB, following fire. Comments: $\mathrm{NaOH}$ pretreatment. (RHD): dates to Period IVB.

\section{P.2376. HAS-72-C14-S17: Period IVB * 1080-1030 $\pm \mathbf{5 0}$ BC}

Charcoal, Provenience Y31 (3) /3/ C14 S2. From upper collapse of Burned Bldg V, over bench in NW corner of columned hall. Bldg was partially reconstructed at start of Period IVB after damaged by fire. Comments: $\mathrm{NaOH}$ pretreatment. (RHD): dates, as expected, to Period IVB.

\section{P-2384-A. HAS-74-C14-S69A:} Period IVB

$$
\begin{array}{r}
2770 \pm 50 \\
* 1010-950 \pm 60 \mathrm{BC}
\end{array}
$$

Charcoal, Provenience V22 W(3) /5/. From S end Rm of Burned Bldg VII. Stratigraphically precedes structure of P-2383, above. Comments: $\mathrm{NaOH}$ pretreatment. (RHD): dates as expected to Period IVB.

\section{P-2394. HAS-74-C14-S93: Periods IVB/IVC}

$$
\begin{array}{r}
2880 \pm 60 \\
* 1110 \pm 60 \mathrm{BC}
\end{array}
$$

Charcoal, Provenience V19/2/. From fill between Walls K and J on W slope of Citadel Mound. On lower slope, Wall K was overlain by Period IVB road system, but remained in use on upper slope. Comment (RHD): dates as expected to end of Period IVC or start of Period IVB.

P-2375. HAS-72-C14-S16: Period IVC $* 1270-1240 \pm 50 \mathrm{BC}$

Charred wood, Provenience W30 C14 S2. Sample was portion of column from E portico of Burned Bldg IV. Portico was built at start of Period IVB. Comments: $\mathrm{NaOH}$ pretreatment. (RHD): either an older tree used for column, or Period IVC wood re-used in Period IVB. 
P-2378. HAS-72-C14-S19: Period IVC

$2990 \pm 170$

Charcoal, from Provenience S22 (8)/11/ C14 S2 on NW Citadel Mound. Sample taken from stratum underlying Period IVB remains and overlying Bldg II of Period V. Comments: sample counted in small counter. (RHD): appears to date to start of Period IV. Sample overlies P-2161, below.

$2980 \pm 40$

P-2385. HAS-74-C14-S32A: Period IVC * 1300-1270 \pm 50 BC

Charred wood, Provenience X32 (5) /3/ C14 S6. Sample was portion of door frame from $\mathrm{N}$ door to columned hall of Burned Bldg V. Comments: $\mathrm{NaOH}$ pretreatment. (RHD): may belong to original structure of Period IVG which was partially renovated at start of Period IVB. Slightly older than expected for Period IVC.

P-2389. HAS-74-C14-S14A: Period IVC

$3000 \pm 60$

Charred wood, Provenience V31 E(3)/2/ C14 S8A. Sample was portion of roof beam in columned hall of Burned Bldg IVE. Comments: $\mathrm{NaOH}$ pretreatment. (RHD): appears to be Period IVC beam re-used in reconstruction of bldg at start of Period IVB.

\section{P-2155. HAS-72-C14-S3: Period V}

$3110 \pm 60$

Charcoal, Provenience V31 (5). From bench on Side of couned hall of Burned Bldg IVE. Sample sealed with debris inside plastered bench. Comments: sample undersized, $88.99 \%$. (RHD): apparently Period $\mathrm{V}$ debris from under Burned Bldg IVE was swept up and used as fill for bldg bench in Period IV.

\section{P-2156. HAS-72-C14-S4: Period V}

$3020 \pm 50$

Charcoal, Provenience DD $30 / 1 /$ (5) C14-2. From structure against $\mathrm{S}$ wall of Burned Bldg II, preceding its construction. Comment (RHD): dates to end of Period V but survived through Period IVB (see P-2392, below).

\section{P-2161. HAS-72-C14-S9: Period V}

$3010 \pm 50$

Charcoal, Provenience S22 Period V Bldg II, and underlying Period IVB strotum, overlying Mound. Comments: $\mathrm{NaOH}$ pretreatment. (RHD): dates to later Period V.

\section{P-2390. HAS-74-C14-S84A: Period V}

$3130 \pm 60$

Charcoal, Provenience V31 E TTI (5)/7/ C14 S26. From structure beneath columned hall of Burned Bldg IVE. Comment (RHD): dates as expected to Period V. 


\section{P2391-A. HAS-72-C14-S13 : Period V $\quad$ 1260-1220 \pm 50 BC}

Charcoal, Provenience Z29 (10A) /1/ /4/ C14 S3A. From structure beneath Rm 6 of Burned Bldg IE (Period IVB) and an underlying foundation (Period IVG ?), between Wall J and S balk of Z29. Comments: $\mathrm{NaOH}$ pretreatment. (RHD): according to pottery, dates to Period V.

\section{P-2392. HAS-72-C14-S20 : Period V}

$2950 \pm 60$

Charred wood, Provenience DD30 (5) /4/ C14 S5. From structure against $S$ wall of Burned Bldg II, preceding its construction. Comments: $\mathrm{NaOH}$ pretreatment. (RHD): this structure probably originates in Period V (see P-2156, above), but survived through Period IVB.

\section{P-2393. HAS-74-C14-S83A: Period V}

$3000 \pm 60$

Charcoal, Provenience V31 TT1 (5) $18 /$ Lot 32 C14 S24 Sample recovered from beneath columned hall of Burned Bldg IVE, between Walls $\mathrm{C}$ and $\mathrm{E}$ of 2 adjoining structures. Comments: $\mathrm{NaOH}$ pretreatment. (RHD): dates, as expected, to Period V.

\section{P-2163. HAS-72-C14-S11: Period VII}

$3970 \pm 50$

Barley grain, Provenience U22 (20)/12/ S5A. Sample recovered from deep sounding in Area U22, on NW Citadel Mound. Comments: $\mathrm{NaOH}$ pretreatment. (RHD): deposit dates to end of Period VII.

\section{Shahr-i Sokhta series}

Shahr-i Sokhta, 59km SSW of Zabol, Sistan prov, Iran $\left(30^{\circ} 44^{\prime} \mathrm{N}\right.$, $61^{\circ} 30^{\prime} \mathrm{E}$ ) is settlement site with 4-period sequence (I-IV) divided into 11 phases (0-10). Period I and Phase 10 are oldest. For other dates from this site, see R, 1977, v 19, p 204-207; R, 1973, v 15, p 593-594. Samples coll 1972 and subm 1976 by Maurizio Tozi, Sem Studi Asiatici, Inst Univ Orientale, Napoli.

General Comment: in sample titles 1st no. represents sec, 2nd no., cut, 3rd no., rm, and last no., layer. Thus XDX.5.CCLXXXV.0 is equivalent to Sec XDX, Cut 5, Rm CCLXXXV, and Layer, none cited.

P.2545. XEU.3.0.1

$4530 \pm 60$

Sample 1, charcoal from horizontal lens of charcoal $8 \mathrm{~cm}$ beneath Cut 3 , in possible aeolian deposit of loose soil. Relevant assemblage Buff Ware of Periods II-III. Comments: $\mathrm{NaOH}$ pretreatment. (MT): dates to Period III (?), Phase 5.

\section{P-2544. EWK.3.DX.2}

$4060 \pm 70$

Sample 8, charcoal from sq hearth of latest stratum predating "large upper structure". Relevant assemblage pottery of Phase IId of "House of 
Stairs". Comments: $\mathrm{NaOH}$ pretreatment. (MT): sample should also date stratum of pottery beneath foundations of $\mathrm{Rm}$ D. Dates to Period II, Phase 5.

\section{P-2542. EW K.8.DVII.4}

$3990 \pm 60$

Sample 10 , charcoal on deposit of clay covering side of $\mathrm{Rm}$, itself directly above clay fill. Relevant assemblage Buff Ware of later Period II, and Gray Ware with close affinities to Rana Ghundai III a-b. Comments: $\mathrm{NaOH}$ pretreatment. (MT): this deposit of smashed bricks and clay probably later than underlying pottery, and contemporary with or slightly earlier than hearth from which P-2544 (below) came. Dates to Period II, Phases 6-5.

\section{P-2546. EWK.8DV.4}

$$
4170 \pm 70
$$

Sample ll, charcoal from container set against $S$ wall. Relevant assemblage Polychrome and grit-tempered wares. Comments: NaOH pretreatment. (MT): container was probably not fireplace. Charcoal may possibly come from later filling (Cuts 3 to 7). Dates to Period II, Phases 7-6.

\section{P-2541. XDX.5.CCLXXXV.3}

$4080 \pm 70$

Sample 19, charcoal from partially burned log, in earthen fill within rm of "House of Buttresses". Relevant assemblage pear-shaped beakers and conical bowls. Comments: $\mathrm{NaOH}$ pretreatment. (MT): may date to final destruction of "House of Buttresses". Dates to Period II, Phase 7.

\section{P-2543. XDV.24.XX.0}

$4200 \pm 60$

Sample 5, charcoal from lens in silty soil between floors dating to Period I. Relevant assemblage Buff Ware. Comments: NaOH pretreatment. (MT): dates to Period I, Phases 9 to 10.

\section{Tall-i-Malyan series}

Tall-i-Malyan, Fars prov, 46km N of Shiraz, Iran $\left(30^{\circ} 3^{\prime} \mathrm{N}, 52^{\circ} 25^{\prime}\right.$ $\mathrm{E})$, is stratified settlement mound, ca 150 ha, occupied during 3rd millennium and 2nd millennium BC. On inscriptional evidence site was id with ancient Elamite capital of Anshan (Sumner, 1973b). For other dates, see R, 1973, v 15, p 594. Samples coll 1972, 1974, subm by William Sumner, Ohio State Univ, Columbus, and R H Dyson, Jr.

\section{P-2059. Sample 136}

Portion of carbonized reed mat from Operation B1, Feature 27, Area 43. Sample contemporary with Operation B, Bldg Level II, where protoElamite tablets and sealings were discovered. Comments: NaOH pretreatment. Possible bitumen contamination may explain anomalous date. 
P.2060. Sample 22

* 1540-1500 $\pm 60 \mathrm{BC}$

Charcoal from Operation EE 41, Lot 29. Sample from bldg containing neo-Elamite tablets. Comment: $\mathrm{NaOH}$ pretreatment.

P.2061. Sample 14

$3060 \pm 60$

* 1400-1380 $\pm 60 \mathrm{BC}$

Charcoal from Operation EE 41, Lot 17. Sample found in bldg containing neo-Elamite tablets.

\section{P-2062. Samples 77 and 78}

$3560 \pm 60$
$* 2070 \pm 60$ вС

Charcoal from Operation C, Area 20, Lot 56, from well containing Kaftari period artifacts, and assoc with Bldg Level I of Operation C. Comment: $\mathrm{NaOH}$ pretreatment.

\section{P-2063. Sample 52}

$3430 \pm 60$

* 1900-1780 $\pm 60 \mathrm{BC}$

Charcoal from Operation C, Area 16, Lot 34, assoc with refuse deposit of Bldg Level I. Comment: $\mathrm{NaOH}$ pretreatment.

\section{P-2185. Sample 1}

$$
\begin{array}{r}
1690 \pm 50 \\
* \text { AD } 270 \pm 50
\end{array}
$$

Charcoal from Operation X-65, Area 5, Stratum 3, Lot 19. Sample provenience $150 \mathrm{~cm}$ from $\mathrm{E}$ balk, next to $\mathrm{W}$ all $\mathrm{H}$, in fill above leveled surface of collapsed kiln, sealed by construction of wall E (Sumner, 1973a).

\section{P-2187. Sample 227}

$4370 \pm 60$

Charcoal from Operation B, Lot 63, Banesh period. For another date of same sample, see TUNC-31, 467l \pm 88 , R, 1975, v 15, p 594.

\section{P-2330. Sample 52a}

$2980 \pm 60$

MF 1249a, wood charcoal from Operation DD 43, Area 14, Lot 43. Sample is portion of roof beam from Middle Elamite bldg. Comment: $\mathrm{NaOH}$ pretreatment.

\section{P-2331. Sample 18}

$2830 \pm 60$

MF 1390A, reed charcoal from Operation CG 43, Area 5, Lot 17, in middle Elamite bldg. Comment: $\mathrm{NaOH}$ pretreatment.

\section{P-2332. Sample 68}

$2950 \pm 60$

MF 1254, reed charcoal from Operation DD 43, Area 15, Lot 49, in Middle Elamite bldg. Comment: $\mathrm{NaOH}$ pretreatment.

P-2333. Sample 40

$4150 \pm 250$

Charcoal from Operation U 168, Lot 61, Banesh period. Comment: $\mathrm{NaOH}$ pretreatment. Sample counted in small counter. 


\section{P-2334. Sample 303}

$4460 \pm 70$

(143, Bldg \pm 80 BC Banesh period. Comment: $\mathrm{NaOH}$ pretreatment.

\section{P-2335. Sample 158}

$4390 \pm 90$

MF 1388, charcoal from Operation ABC-N, Area 3, Lot 90, between Bldg Levels II and III, Banesh period. Comment: $\mathrm{NaOH}$ pretreatment.

\section{P-2336. Sample 346}

$4630 \pm 260$

Charcoal from Operation $A B C-N$, Pit 84 Sample provenience Level IV, Banesh period. Comment: $\mathrm{NaOH}$ pretreatment. Sample counted in small counter.

2. Israel

\section{P-2572. Tell Qiri (Hazorea)}

$3740 \pm 230$ of Tell Qiri (Hazorea), (32 $38^{\prime} \mathrm{N}, 35^{\circ} 6^{\prime} \mathrm{E}$ ). Site revealed remains extending from Chalcolithic into Roman periods with Iron age remains particularly prominent (Ben-Tor 1975; 1976). Coll 1976 and subm by Amnon Ben-Tor, Inst Archaeol, Hebrew Univ Jerusalem. Comment: sample counted in small counter.

3. Jordan

\section{P-2573. Bab-Edh-Dhra}

$3770 \pm 60$

Olive stones from ash pit, Phase 3, Area X, of Early Bronze age site of Bab-Edh-Dhra, S Ghor, Jordan ( $\left.31^{\circ} 15^{\prime} \mathrm{N}, 35^{\circ} 33^{\prime} \mathrm{E}\right)$. Sample from earliest habitation Level $\mathrm{E}$ of walled town, of Early Bronze IV A date, ca 2300-2200 BC (see Schaub, 1973). For other dates from same site see R, 1970, v 12, p 179. Coll 1975 by R Thomas Schaub, Indiana Univ Pennsylvania; subm 1976 by James Weinstein, Univ Mus, Univ Pennsylvania.

\section{Pakistan}

$$
\text { C. SW Asia }
$$

\section{P-2476. Jhukar}

$4630 \pm 300$

Charcoal from oven in Trench C IV, Layer 15, Mound A, of Harrapan period site of Jhukar, Larkana dist, Sind prov, Pakistan $\left(37^{\circ}\right.$ $33^{\prime} \mathrm{N}, 68^{\circ} 8^{\prime} \mathrm{E}$ ). For site survey, see Majumdar (1934). Coll 1974 by $\mathrm{M}$ Rafique Mughal, subm 1976 by Dept Archaeol \& Mus, Govt Pakistan, Karachi. Comment: sample counted in small counter.

\section{Loebanr III series}

Loebanr III is small settlement site $\left(34^{\circ} 52^{\prime} \mathrm{N}, 72^{\circ} 23^{\prime} \mathrm{E}\right)$ in Swat valley, Pakistan. Cultural horizon of site can probably be ascribed to 
Period IV in sequence of protohistoric cultures of Swat valley, and shows close relationship with Neolithic Phase II of Burzahom in Kashmir (Stacul, 1976). For other dates related to Period IV from site of Aligrama (Stacul \& Tusa, 1975), see P-2151, $3010 \pm 60$, and P-2152, $3350 \pm 40$ (both R, 1977, v 19, p 214). Samples coll 1976 and subm 1977 by Giorgio Stacul, Inst Storia Antica, Univ Trieste, Italy.

\section{P-2583. Sample 1}

$3280 \pm 90$

$1650 \pm 90 \mathrm{BC}$ ple underized $(91.8 \%)$, larger uncertainty than other samples in series.

\section{$3140 \pm 60$}

P-2584. Sample 2

Charcoal from Pit 1, Layer 6.

$* 1500 \pm 60 \mathrm{BC}$

\section{P-2585. Sample 3}

$3250 \pm 60$

Charcoal from Pit 1, Layer 7 .

$* 1640-1600 \pm 60 \mathrm{BC}$

P-2586. Sample 4

$3360 \pm 60$
$* 1730-1690 \pm 60 \mathrm{BC}$

Charcoal from Pit 2, Layer 5. Comment: $\mathrm{NaOH}$ pretreatment.

\section{Sri Lanka (Ceylon)}

\section{Kantarodai series}

Charcoal from site of Kantarodai, Jaffna, Sri Lanka $\left(10^{\circ} 0^{\prime} \mathrm{N}, 80^{\circ}\right.$ $1^{\prime} \mathrm{E}$ ). Site contains complex stratified sequence covering pre-Anuradhapura period and, in its middle phase, displays close connections with Arikamedu in S India. One Roman carnelian seal was recovered from Trench A, in Rouletted Ware strata. Samples coll 1970 by Bennet Bronson, Field Mus Nat Hist, Univ Chicago, Chicago, Illinois, and Mohammed Mauro, Univ Pennsylvania, and subm 1976 by Bennet Bronson.

General Comment (BB): although overall time span indicated by radiocarbon dates seems reasonable, stratigraphic order suggested by certain dates is problematic, particularly very young date of Sample P-2526.

\section{P-2529. Sample 6, Lot 7}

$2350 \pm 200$

Ptratum. III, Trench X, from late pre-Rouletted Ware context (2nd phase), at depth of 76 to $79 \mathrm{~cm}$. Comment: sample counted in small counter.

\section{P-2521. Sample 4, Lot 13}

$2020 \pm 50$ Ware (3rd phase), at depth 55 to $59 \mathrm{~cm}$. 
P-2518. Sample 5, Lot 13

$$
2290 \pm 50
$$

$* 420 \pm 50 \mathrm{BC}$

From Refuse Pit 4, Stratum IV, Trench A, assoc with Rouletted Ware (3rd phase), at depth 55 to $59 \mathrm{~cm}$. Comment: $\mathrm{NaOH}$ pretreatment.

\section{P-2517. Sample 12, Lot 16}

$2250 \pm 50$

Stratum IV or V, Trench X, Phase 1 or 2. Comment: NaOH pretreatment.

\section{P.2514. Sample 1, Lot 8}

$2250 \pm 60$

From surface of Stratum V, Trench $B$, underlying Rouletted Ware strata (3rd phase), at depth of 72 to $81 \mathrm{~cm}$.

\section{P-2520. Sample 8, Lot 21}

$2180 \pm 60$

Pit 6, Stratum V, Trench A, Rouletted Ware context (Phase 3), at depth 85 to $92 \mathrm{~cm}$.

\section{P-2524. Sample 9, Lot 22}

$2340 \pm 50$ outside pit containing P-2520, above, at depth 90 to $96 \mathrm{~cm}$.

\section{P-2515. Sample 2, Lot 10}

$* 440 \pm 50$ BC Phase), at depth 91 to $98 \mathrm{~cm}$.

\section{P-2516. Sample 3, Lot 12}

$2990 \pm 60$

$* 1290 \pm 60 \mathrm{BC}$

From Stratum VI, Trench B, at depth 125 to $130 \mathrm{~cm}$. Comment: $\mathrm{NaOH}$ pretreatment.

\section{P-2522. Sample 7, Lot 21}

$2110 \pm 60$

Lower part of Stratum VII, Trench B, assoc with Phase 2 ceramics, at depth 125 to $225 \mathrm{~cm}$.

\section{P-2523. Sample 16, Lot 27}

$2060 \pm 50$

Stratum VIII, Trench $\mathrm{B}$, assoc with Phase I pottery, at base of stone "wall", within sherd pavement, at depth $280 \mathrm{~cm}$.

\section{P-2525. Sample 16, Lot 28}

$2730 \pm 220$

Stratum VIII, Trench B, in Phase 1 context, at depth $290 \mathrm{~cm}$. Comment: sample counted in small counter.

P-2519. Sample 17, Lot 30

$2290 \pm 60$

$* 420 \pm 60 \mathrm{BC}$

Stratum IX, Trench B, in early Phase 1 context, at depth $315 \mathrm{~cm}$. Assoc pottery stylistically undefinable. Comment: $\mathrm{NaOH}$ preteatment. 
P-2526. Sample 18, Lot 31

$* 190-140 \pm 50 \mathrm{BC}$

Stratum X, Trench B, at depth 390 to $395 \mathrm{~cm}$, in Phase I context lacking pottery, overlying naturally deposited layer of small stones. Comment (BB): deepest and presumably earliest sample from site.

\section{P-2528. Sample 19}

$2370 \pm 60$

Lot 35 , Stratum XI, Trench B, at depth 345 to $350 \mathrm{~cm}$, in presumably Phase 1 context, assoc with worn sherds and some bones.

\section{United States}

\section{B Lawrence I Rockshelter series}

B Lawrence I Rockshelter (47-Ve-154), in Kickapoo Valley, Vernon Co, Wisconsin $\left(43^{\circ} 36^{\prime} \mathrm{N}, 90^{\circ} 37^{\prime} \mathrm{W}\right)$, Amerindian shelter site with 6 cultural levels (VI, oldest, to I, most recent) interleaved with mostly sterile strata. All cultural levels but Level I are aceramic. Of some 450 sites retrieved through salvage archaeol in Kickapoo Valley, only B Lawrence I Rockshelter yielded sufficient material for ${ }^{14} \mathrm{C}$ dating. Dates from this site will establish chronologic framework for entire valley. All samples coll 1974 by John Halsey, subm 1976 by Barbara Mead, both, State Hist Soc Wisconsin, Madison.

\section{P-2462. Sq 7Ø, Level I}

$1080 \pm 60$

* AD $910 \pm 60$

Wood, charcoal, and nutshell (id as Carya ovata by B Mead) from midden deposits in Sq $7 \varnothing$, middle of cultural Level I. Assoc with triangular and side-notched triangular points, and smoothed over cordmarked ceramics, at depth of $28.3 \mathrm{~cm}$. Comment (BM): projectile points are usually considered to be Late Woodland, while ceramics considered to be Middle Woodland.

\section{P-2463. Sq 6Ø, Level I}

$880 \pm 60$ and side-notched triangular points, and smoothed-over cord marked ceramics, at depth $57 \mathrm{~cm}$. Comment (BM): see above.

\section{P-2464. Sq 6A, Level II}

$1840 \pm 50$

* AD 110-130 \pm 50

Wood charcoal from $\log$ in midden deposit, assoc with Durst Stemmed points, at depth $75.9 \mathrm{~cm}$. Comments: $\mathrm{NaOH}$ pretreatment.

\section{P-2465. Sqs 10, 4Ø, Level III}

$3040 \pm 250$

Woot corth, Feature 13, assoc as P-2466, below, at depth $176.8 \mathrm{~cm}$. Comments: $\mathrm{NaOH}$ pretreatment. Sample counted in small counter. 
P-2466. Sq 5A, Level III

Wood charcoal from hearth, Feature 112, assoc with Durst Stemmed projectile points Late Archaic), at depth $191.1 \mathrm{~cm}$. Comment (BM): $\mathrm{NaOH}$ pretreatment; no Durst point components have yet been dated in Wisconsin.

\section{P-2467. Sq 3A, Level IV}

$3090 \pm 250$ depth $226.5 \mathrm{~cm}$. Comment: sample counted in small counter.

\section{P-2468. Sq 5A, Level IV}

$3150 \pm 260$

Wood $1500 \pm 260 \mathrm{BC}$ Notched projectile points projectile points, at depth $226.5 \mathrm{~cm}$. Comment: sample counted in small counter.

\section{P-2469. Sq 6C, Level V}

$3500 \pm 70$

Wood che $2040-2020 \pm 70$ BC Notched and large straight stemmed prosit, assoc with Raddatz SideComment: $\mathrm{NaOH}$ pretreatment.

\section{P-2475. Elephant Hill, Vermont}

$39 \pm 38$

Fragment of $\log$ from $S$ side of passageway leading into structure on Theodore Fouck property, Elephant Hill, NE of S Royalton, Vermont $\left(43^{\circ} 49^{\prime} \mathrm{N}, 72^{\circ} 30^{\prime} \mathrm{W}\right)$. Log lay between 2 capstones and other stones which served as posts framing this passageway. Coll 1976 and subm by Vincent Malmström, Dartmouth Coll, Hanover, New Hampshire. Comments: age precedes nuclear bomb tests of last decade, but more precise date cannot be estimated (VM). Structures similar to this one are common in $\mathrm{N}$ New England; their origins have been subject of persistent controversy.

\section{Quiriqua series}

\section{E. Guatemala}

Quirigua is Lowland Mayan site of Classic period, Dept Izabal, Guatemala $\left(15^{\circ} 16^{\prime} \mathrm{N}, 89^{\circ} 03^{\prime} \mathrm{W}\right)$. Samples coll 1975 and 1976 ; subm 1976 by Robert Sharer, Univ Mus, Univ Pennsylvania.

\section{P-2534. Ref No. 8L/4-1}

$1140 \pm 50$

Fragments of carbonized wood, 0.66 to $0.69 \mathrm{~m}$ betow on threshold of Str 2C-3, Loc 026 , Assoc $\mathrm{NaOH}$ pretreatment. (RS): classic-Early Postclassic periods, ca AD 700 to 1000 , although precise stratigraphic relation to other samples in series is uncertain. 
P-2532. Ref No. 8L/5-1

Fragments of carbonized wood, 0.54 to $0.64 \mathrm{~m}$ below ground surface, on surface of "BEAN" floor, Loc 026. Assoc with floor. Comment (RS): expected date in Late Classic or Early Postclassic periods, ca AD 700 to 1000.

\section{P-2533. Ref No. 6G/6-2}

$1150 \pm 50$

* AD 830-850 \pm 50

Fragments of carbonized wood, 0.98 below ground surface, in N-S trench below "HAZ" layer, among interstices of "SAL" paving lajas, and assoc with "SAL" pavement. Comments: $\mathrm{NaOH}$ pretreatment. (RS): expected date in Late Classic period, ca AD 600 to 900.

\section{P.2535. Ref No. 6I/15-1}

$1130 \pm 180$

* AD 860-880 \pm 180

Fragments of carbonized wood, $2.78 \mathrm{~m}$ below ground surface at $\mathrm{N}$ base and inside corner of assoc buried Acropolis structure "RAT". Comments: sample counted in small counter. (RS): expected date later than P-2533, above, but still within Late Classic period, ca AD 600 to 900 .

\section{P-2536. Ref No. 6I/27-1}

$1400 \pm 50$

* AD $590 \pm 50$

Fragments of carbonized wood, $3.08 \mathrm{~m}$ below ground surface, in fill NE of and below "TOM" structure. Fill appears to predate this structure. Comments: $\mathrm{NaOH}$ pretreatment. (RC): expected date earlier than P-2535, above, but still within Late Classic period, ca AD 600 to 900.

\section{P-2537. Ref Nos. 13N/18-2, 13N/18-3}

$1580 \pm 190$

Fragments of carbonized wood, 1.2 to $1.4 \mathrm{~m}$ below ground surface, toward base of pit beyond N end of Structure 3C-2, Loc 029. Comments: $\mathrm{NaOH}$ pretreatment. Sample counted in small counter. (RS): expected date Late Classic period, ca AD 600 to 900 , although precise stratigraphic relation to other samples in series is uncertain.

\section{P-2531. Ref Nos. 6L/11-1, 6L/11-2}

$4660 \pm 270$

(280 $\mathrm{N}$ facade in axial trench of "PINA" structure on Acropolis. Assoc with fill predating "SANDIA" floor. Comments: sample counted in small counter. (RS): presumed dated to Late Classic period, ca AD 600 to 900, although difficult to assess age relative to other samples in series.

\section{P-2538. Ref No. 6F/17-2}

$1100 \pm 170$

$$
\text { * AD } 890 \pm 170
$$

Fragments of carbonized wood, 0.06 to $1.05 \mathrm{~m}$ below ground surface, $\mathrm{W}$ of "BOM" wall in fill of sub-"BOT" floor on Acropolis. Fill apparently predates "BOT" floor. Comments: sample counted in small coun- 
ter. (RS): expected date in Late Classic period, ca AD 600 to 900, although precise stratigraphic relationship to other samples in series is uncertain.

\section{Hamanasuno series}

$$
\text { F. Japan }
$$

Hamanasuno is single component Early Jomon site with slight traces of Middle Jomon horizon $\left(41^{\circ} 50^{\prime} \mathrm{N}, 141^{\circ} 00^{\prime} \mathrm{E}\right)$ Minamikayabe, Japan (Hurley, 1974). Radiocarbon and thermoluminescence dates from site have aided construction of chronology for Early Jomon period (Hurley et al, ms in preparation). Samples coll 1975 by William Hurley, Univ Toronto, Ontario, Canada; subm 1976 by William Hurley and Gary Crawford, Univ North Carolina, Chapel Hill.

\section{P-2459. House 31, Pits 2, 3, and 5}

$4430 \pm 90$

Charcoal, composed of deciduous hardwoods, cor 2, 3 , and 5 in House 31. Comments: NaOH pret, combined from Pits undersized $(63 \%)$ for $8 \mathrm{~L}$ counter. Date is average, weighted Sample was tainties of 3 counts in $8 \mathrm{~L}$ counter and 1 count in $1 \mathrm{~L}$ counter. Counts are statistically consistent for quoted age and uncertainty.

\section{P-2460. House 30a, Level X3}

$4960 \pm 350$

Charcoal from House 30a, Grid G25-25, Subsquare 0, Level X 3 house floor. Comments: $\mathrm{NaOH}$ pretreatment. Sample counted in small counter.

\section{P-2470. House 30a, Level X3}

$5420 \pm 330$

Charcoal from floor. Comment: sample counted in small counter.

\section{P-2461. House 32, Pits 6, 7, and 8}

$4650 \pm 330$

Charcoal combined from Pits 6, 7 , and 8 , wc-6. Comment: sample counted in small counter.

\section{P-2471. Grids G 28-23, G 29-23}

$5680 \pm 380$ adjacent to Pithouse 33. Comment: sample counted in small counter.

\section{P-2472. House 27}

Charcoal from floor. Comment: sample counted in small counter.

\section{REFERENCES}

Barker, Harold, Burleigh, Richard, and Meeks, Nigel, 1969, Briiish Muscum radiocarbon measurements VI: Radiocarbon, v 11, p 2i8-294.

Barker, Harold and Mackey, John, 1963, British Museum natural radiocarbon measurements IV: Radiocarbon, v 5, p 104-108.

Ben-Tor, Amnon, 1975, Tell Qiri (Hazorea): Israel Explor Jour, v 25, p 168-169. 1976, Hazorea: Israel Explor Jour, v 26, p 200-201. 
Betancourt, P P and Weinstein, G A, 1976, Carbon 14 and the beginning of the late bronze age in the Aegean: Am Jour Archaeol, v 80, no. 4, p 329-348.

Bovington, Charles, Mahdavi, Azizeh, and Masoumi, Roghiyeh, 1973, Tehran University Nuclear Centre radiocarbon dates II: Radiocarbon, v 15, p 592-598.

Cadogan, G, Harrison, R K, and Strong, G E, 1972, Volcanic glass sherds in late Minoan I Crete: Antiquity, v 46, no. 184, p 310-313.

Caskey, J L, 1971, Investigations in Keos, part I: Hesperia, v 40, p 358-396.

- 1972, Investigations in Keos, part II, a conspectus of the pottery: Hesperia, v 41, p $375-401$.

Catling, H W, 1974, Archaeology in Greece, 1973-74; Archaeol Repts for 1973-74, no. 20, p $3-41$.

Crane, H R and Griffin, J B, 1970, University of Michigan radiocarbon dates XIII: Radiocarbon, v 12, p 161-180.

Dikaios, Porphyrios, 1953, Khirokitia: Oxford, Oxford Univ Press, 447 p.

1960, A conspectus of architecture in ancient Cyprus: Nicosia, $30 \mathrm{p}$. 1962, The stone age: Swedish Cyprus Exped, v 4, pt la, p 1-192.

Dyson, R H Jr, 1972, The Hasanlu project, 1961-67: Memorial vol, 5th internatl cong of Iranian art and archaeol, v 1, Tehran 1968, p 39-58.

1974, Hasanlu, 1974: the ninth century b.c. gateway: 3rd ann symposium on archaeol research in Iran, Proc, Tehran 1974, p 179-188.

Fishman, Bernard, Forbes, Hamish, and Lawn, Barbara, 1977, University of Pennsylvania radiocarbon dates XIX: Radiocarbon, v 19, p 188-228.

Hurley, W M, 1974, The Hamanasuno project: Arctic Anthropologist 11, supp, p 171-176.

Majumdar, N G, 1934, Exploration in Sind: Mem Archaeol Survey of India, no. 48, p 5 - 18 .

Michael, Henry, 1976, Radiocarbon dates from Akrotiri on Thera: Temple Univ Aegean symposium, Philadelphia, 1976, p 7-9.

Michael, Henry and Ralph, Elizabeth K, 1974, University of Pennsylvania radiocarbon dates XVI: Radiocarbon, v 16, p 198-218.

Pichler, Hans and Friedrich, Walter, 1976, Radiocarbon dates of Santorini volcanics: Nature, v 262, no. 5567, p 373-374.

Ralph, Elizabeth K, 1959, University of Pennsylvania radiocarbon dates III: Am Jour Sci Radiocarbon Supp, v 1, p 45-58.

Ralph, Elizabeth K, Michael, Henry N, and Han, Mark C, 1973, Radiocarbon dates and reality: MASCA Newsletter, v 9, no. 1, August, p 1-20.

Schaub, R T, 1973, An early bronze IV tomb from Bab edh-Dhra: Am Schools Oriental Research Bull, no. 210, April, p 2-37.

Stacul, Giorgio, 1976, Excavation at Loebanr III (Swat, Pakistan): East and West n s, v 26, no. 1-2, March-June, p 13-30.

Stacul, Giorgio and Tusa, Sebastiano, 1975, Report on the excavations at Aligrama (Swat, Pakistan) 1966, 1972; East and West, n s, v 25, no. 3-4, Sept-Dec, p 291-321.

Stuckenrath, Robert Jr, 1963, University of Pennsylvania radiocarbon dates VI: Radiocarbon, v 5, p 82-103.

Stuckenrath, Robert Jr, Coe, William R, and Ralph, Elizabeth K, 1966, University of Pennsylvania radiocarbon dates IX: Radiocarbon, v 8, p 348-385.

Stuckenrath, Robert Jr and Lawn, Barbara, 1969, University of Pennsylvania radiocarbon dates XI: Radiocarbon, v 11, p 150-162.

Sumner, William, 1973a, Survey of excavations: Malyan: Iran XI, p 199-200. p 304.

Taylour, Lord William D, 1972, Excavations at Ayios Stephanos: British School at Athens Ann, v 67, p 205-270.

\section{Corrections}

1. R, 1977, v 19, p 214: 2nd sample numbered P-2151, $3350 \pm 40$, should have been numbered P-2152.

2. R, 1977, v 19, p 194: P-2403, Nuraghe Genna Maria, Villanovaforru, Sardinia. MASCA corrected date should be $* 1210-1100 \pm 50$ вс. 